\title{
シンポジウム
}

\section{新臨床研修制度の改善一教育病院からの提言 \\ 2. 大学病院からの提言}

嘉山 孝正

〔日内会誌 99：2790～2795，2010〕

Key words : Seamless education, Basic medicine, Top runner

はじめに

新臨床研修制度以前の日本の医学教育は, 卒 前にある範囲の医行為まで研修させ，医師国家 試験取得後は欧米と同様に 70〜80\%は, 自校の 大学医学部附属病院で専門教育に入っていった. 所謂入局をしていたわけである。 そこで先輩か ら教えを受け，尊敬する恩師がいて生涯教育の スタートをきる風景があった(図 1)。その結果, 日本の医療のWHO(World Health Organization) の評価で世界一であった。健康レベルの評価で はなく，医療の質，すなわち，がんの死亡率， 糖尿病の死亡率等の評価がほとんどAランクで, 総合でも一位である（図 2)，然るに，欧米の医 学教育がよいとの, 未だ後進国精神で, 得意の キャッチアップを図るベくレベルの低い医師を 最終的には創成する制度を取り入れた。 その結 果, 地方はおろか東京をも含めた医療崩壊が起 きた。ささに科の偏在も著明化した。旧来の入 局制度に戻るのが良いというわけではないが, 新臨床研修制度と旧来の制度の特徵を検証し, 現臨床研修制度の改善を提言する。

かやま たかまさ：国立がん研究センター, 山形大学 (休職中)

\section{1． 新臨床研修制度導入の背景}

平成 16 年から本制度は導入されたが, 多くの 反対を見越したように医療事故の記事がマスコ ミに溢れんばかりに登場し, 多くの論調は, プ ライマリーケアーが研修されていないからだ， に終始していた．筆者も学部教育が悪いために 種々の医療事故が起きていると思った時期もあっ た。しかし，日本人は風に乗って物事を考える ことがくせになっているせいか，これらの医療 事故？との報道をきちんと検証しなかった。よ く考えれば解るように, 患者取り違えや割り箸 事故はプライマリーケアーとは全く関係がない 悲しい事故であった．医療費の抑制に伴う人員 不足や世界で初めてで症例報告になるような例 をプライマリーケアーができないからと錯覚し たのである，そうでなければ，旨くいっている と社会が考える教育を変革することは困難であっ た，従って，本制度導入には，プライマリーケ アーの教育不足を解消するなどと言う理由では ない別の理由があったと考える，それは，医療 費削減であり, 大学医学部附属病院が持ってい る医局制度の破壊であったと考える。実際, 現 在も専門医が多いという議論を巻き起こしてい るのが新臨床研修制度推進派で, 同じ顔ぶれで 


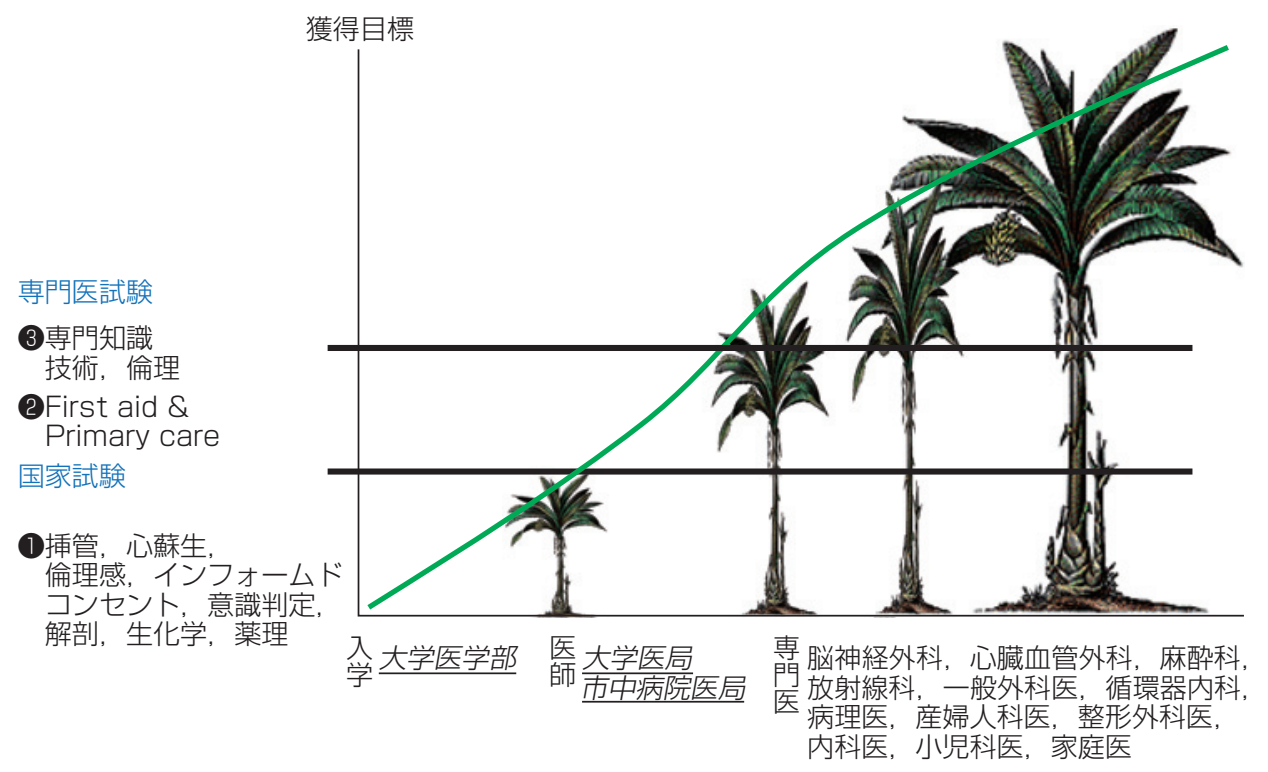

図 1. 新臨床研修制度以前の日本の医師の成長

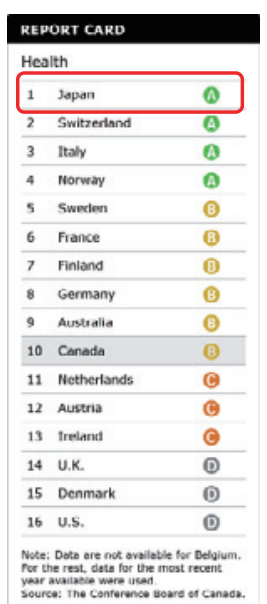

総合評価

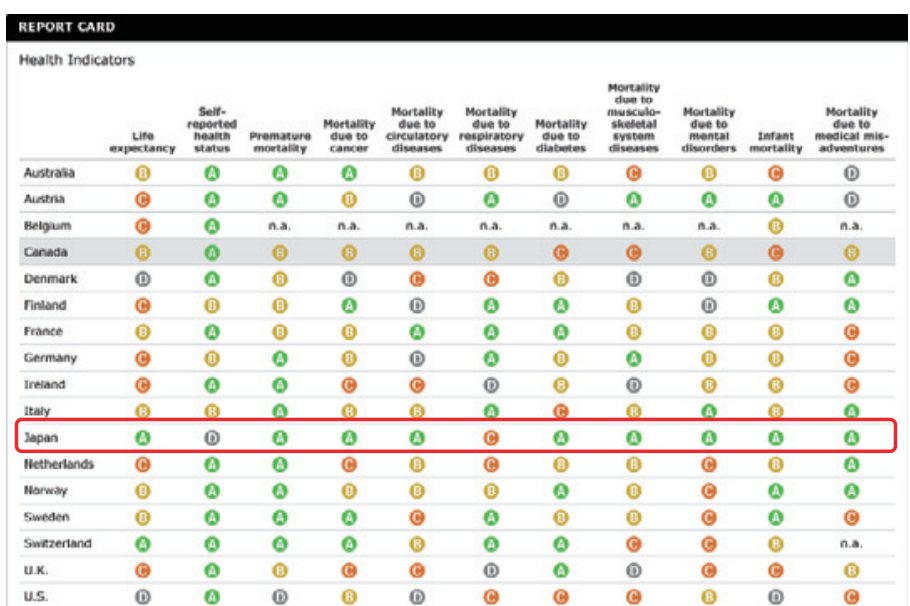

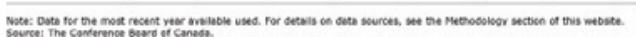

\個別指標の評価

図 2. 世界一の日本の医療〜 Health Data 2009 でも総合 1 位〜

OECD, Health Data 2009 に基づく Conference board of Canada の国際評価

ある。くり返すが，日本の医療の質は世界一な のである.確かに医局制度には種々の欠点もあっ たことは事実である。しかし，教授の人望，能 力が高ければ医師一人一人の能力や性格を的確 に評価し, 地方病院から都会の病院まで, 最小 限の医師数で配置していたのである。医師数の
絶対值が先進国では少ない事実はあったが，日 本人特有のどうにかしてしまう能力で支え切れ ていたのである。この世界でも希に見る素晴ら しい制度を変革させたのが新臨床研修制度であっ た. 
2 具体的目標

（1）基本的診察法

卒前に修得した事項を基本とし，受持症例について例えば以下につき主要な所見を正確に把握できる

1）面接技法（患者，家族との適切なコミュニケーションの能力を含む）

2）全身の観察（バイタルサイン，精神状態，皮膚の診察，表在リン八節の診察を含む）

3）頭・頸部の診察（眼底検査，外耳道，鼻腔，口腔，咽頭の観察，甲状腺の触診を含む）

4）胸部の診察（乳房の診察を含む）

5）腹部の診察（直腸診を含む）

6) 泌尿・生殖器の診察（注：産婦人科の診察は指導医と共に実施のこと）

7) 骨・関節・筋肉系の診察

8) 神経学的診察

（2）基本的検査法（1）

必要に応じて自ら検査を実施し，結果を解釈できる。

1）検尿

2) 検便

3）血算

4）出血時間測定

5）血液型判定 · 交差適合試験

6）簡易検査（血糖，電解質，尿素窒素，赤沈を含む）

7）動脈血ガス分析

8) 心電図

9）簡単な細菌学的検査（グラム染色，A群 $\beta$ 溶連菌抗原迅速検査を含む）

図 3. 卒後臨床研修目標（医道審議会臨床研修検討部会）

医学系の学習・評価項目（第 2 版，平成 18 年 9 月）

I 、診察に関する共通の学習・評価項目 : プライバシ一や苦痛への配慮，身だしなみ，言葉遣い，挨拶や説明

II. 医療面接 : 導入部分, 患者さんとの良好なコミュニケーション, 患者さんに聞く (医学的情報, 心理・社 会的情報)，患者さんに話を伝える，締めくくり部分，全体をとおして，報告

III. 全身状態の把握：第一印象，視診，触診，反応，臭い，バイタルサイン，身体計測

IN.バイタルサインの測定（四肢動脈の診察などを含む）：診察時の配慮，意識レベル，体温，呼吸，上肢の脈 拍・血圧測定, 下肢の脈拍・血圧測定, 下肢浮腫の診察

V. 頭頸部診察：診察時の配慮, 頭部の診察, 頸部の診察

VI. 胸部診察 : 診察時の配慮, 聴診器の使用, 肺の診察（前胸部，背部)，その他背部の診察，心臟の診察，頸 部血管の診察, 乳房の診察（シミュレーター使用）

VII. 腹部診察：診察時の配慮, 全般的注意事項, 基本的診察法, 病態に応じた精密診察法

VII. 神経診察 : 診察時の配慮, 診察の順序, 脳神経系の診察, 上肢の運動系の診察, 上肢の握力の診察と徒手 筋力検查, 起立と歩行の診察, 下肢の運動系の診察, 下肢の徒手筋力検査, 感覚系の診察, 反射の診察, 髄膜刺激徵候の診察, 認知機能の診察, 意識レベルの診察

IX. 外科系基本手技：診察時の配慮，病棟手洗い，静脈採血，持続的導尿（男性，女性），手術時手洗い・ガウ ンテクニック, 縫合

X. 救急：成人の心肺蘇生法, 小览の心肺蘇生法, 意識障害患者への初期対応, 気道異物による窒息への初期 対応, 穌生チームによる心肺蘇生法, 重症救急病態に対する救命治療, 初期救急病態の鑑別と初期治療

図 4. Objective Structured Clinical Examination : OSCE

\section{2. 新臨床研修制度の検証}

新臨床研修制度の骨格は，種々の分野のプラ イマリーケアーの習得である。さらに重要なこ
とは，医学部卒業生全員に強制することであっ た．自由を謳ってはいるが，実質は強制であっ て, 事実 $100 \%$ 近い医学部卒業生が新臨床研修 制度に参画した。エビデンスとして強制と判断 される制度である. その内容を検証すると, CBT 


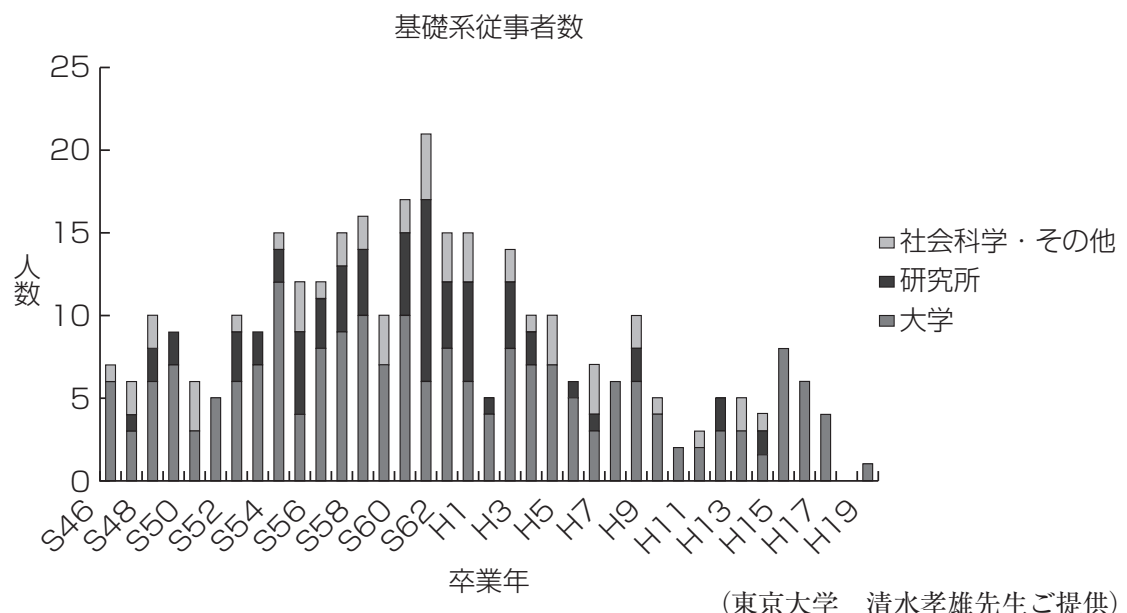

図 5. 医学研究の崩壞 東京大学医学部卒業者のうちで基礎研究に携わる研究者数 の推移

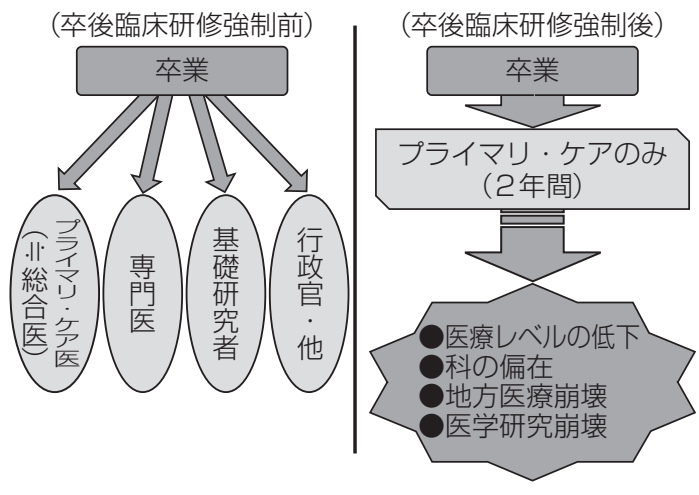

図 6. 医学部卒業生のキャリアパス

(computer based test) と殆ど同じ内容が並んで いる. それは当然のことであって, 学部教育で, 実習を殆どしていないという前提で作成してい るからである.しかし, 4 年生から 5 年生に掛け て座学としては終わり, CBTのadvanced OSCE では，実習をすることになっているために同じ 内容になることは当然である (図 3，4).さらに 医師国家試験でもその習得すべき内容のほぼ大 半が, CBT, 国家試験, 新卒後臨床研修制度が 重なっているのである. 3 回も同様の獲得目標を かしている国などあり得ない制度を施行してい るのである。ささらに本制度で起きた大きな負の 遺産は基礎研究者の減少である. 図 5 は東京大
学の清水医学部長から頂いた資料であるが, 多 くの優れた研究者を排出してきた東京大学です ら基礎研究者が 0 の年がでたのである。私は, 日本の医療の質が, どのような医師でも若い時 代に研究マインドが育成されたからこそ, 開業 医となってもその質が落ちないために日本の医 療の質が保たれたと確信している。 その基盤が 破壊されたことがこの制度の最も大きな負の遺 産であると考える，本制度を創成した人々の責 任は大きいと言える.

\section{3. 旧制度の検証}

新臨床研修制度以前, 医学部卒業生は, 図 6 の左図の如く, 各分野へ進み, 高度医療から地 方医療まで幅広く, また, 世界のトップランナー をも育成でき, 基礎研究者も十分に育っていた. その結果が図 2 で示される結果である. 日本の 医学者のノーベル賞での医学生理学賞が少ない との批判があるが，それは欧米と比較し，その 研究予算額とシステムの相違が大きいといえる. また, 旧制度では，医師の生涯教育と地域医療 が旨くかみ合い, 医師同士の連携も医局を中心 に円滑に行われていて, 科の偏在も地域医療の 


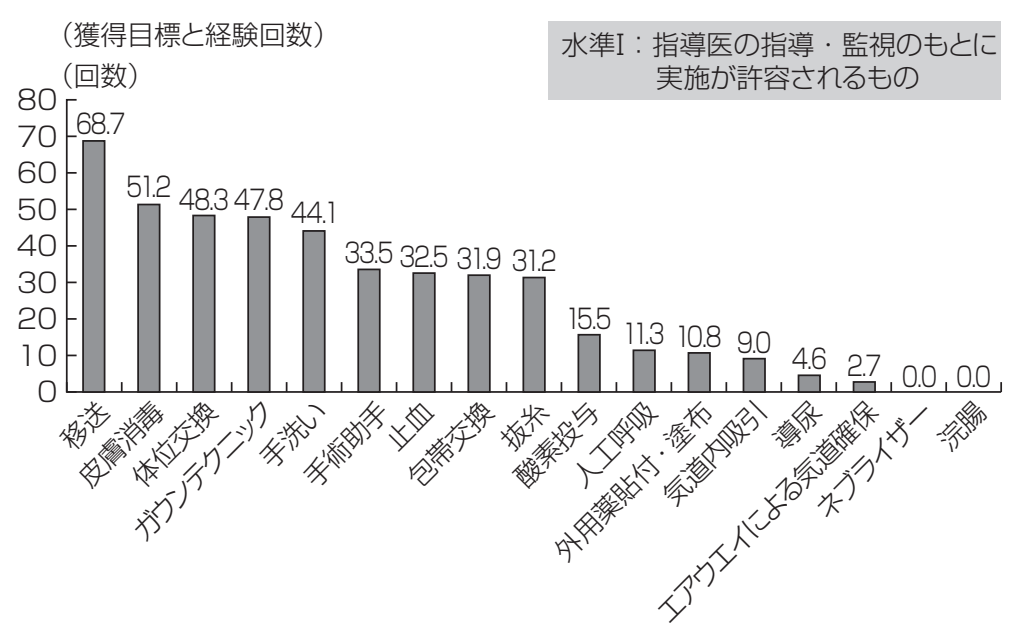

(出典：2009年山形大学医行為実施調查)

図 7. 水準 I一検查

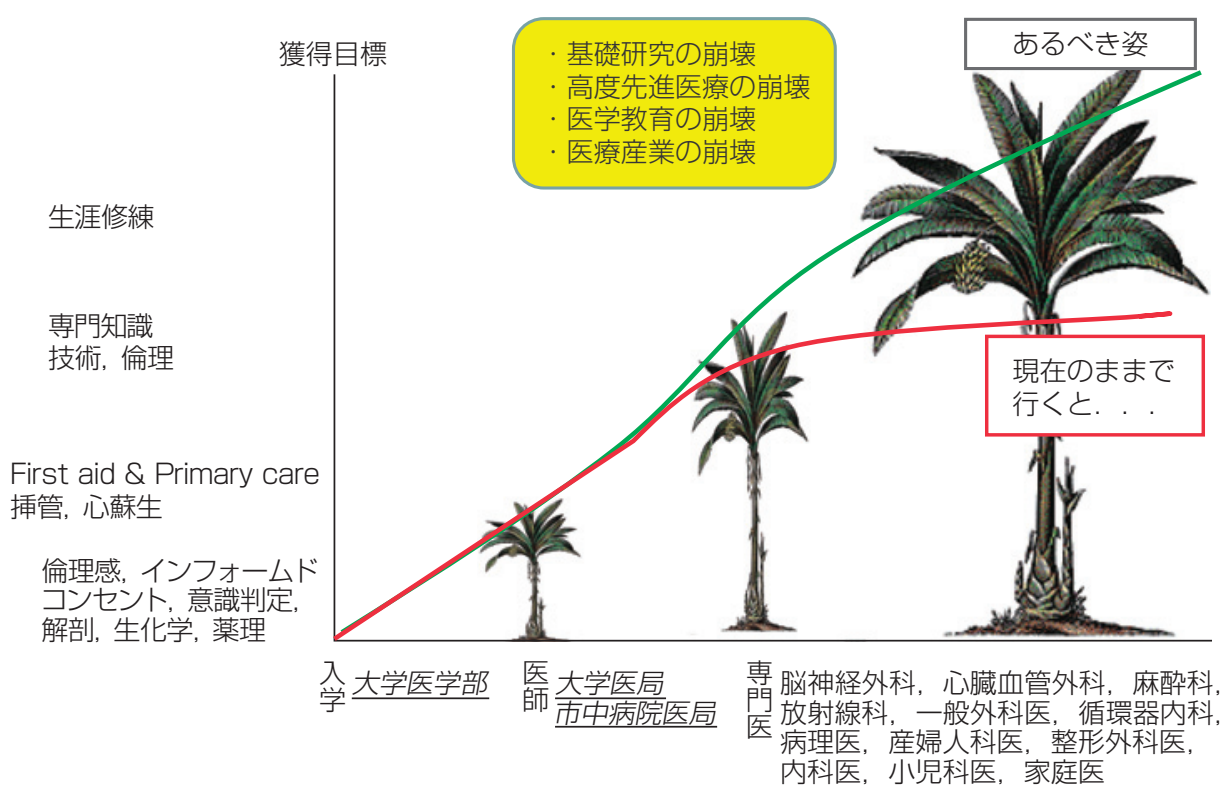

図 8. 今後の医師の成長

崩壊の顕在化もかろうじて防いでいたと言える. しかし，医局の統括者たる教授の管理運営能力 がなければその弊害が大きいのは当然であり， それは, 一部の教授がそうだったから記事になっ たのであり，多くの医局運営は健全に行われて いたからこそ，図 2 の結果が出たのである。し かし, 現時点では大学医学部の自浄作用はかな
りなされていたが，新臨床研修制度の創世記に は十分でなかったことは容認せざるをえない.

\section{4. 提言}

私は, プライマリーケアー医が必要ないとい う論の立場の人間ではないが, 新臨床研修制度 


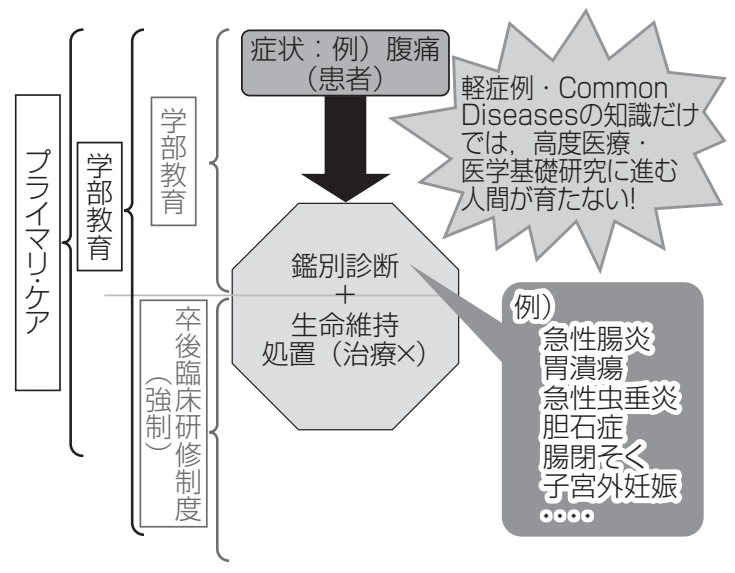

図 9. 今後, 目指すべき方向

が, 基礎研究の崩壊, それに伴う医師の研究マ インドの喪失が日本の医療, 医学研究へ与えた 影響は甚大で歴史に残る悪制度と考える.そこ で, 提案であるが, 学部教育と卒後研修をシー ムレスにするために 2 度 3 度と同じ医行為をさ せないで, 学部学生の内に生命救急ができる医 行為を学生時代に勉強させて（図 7), それ以後

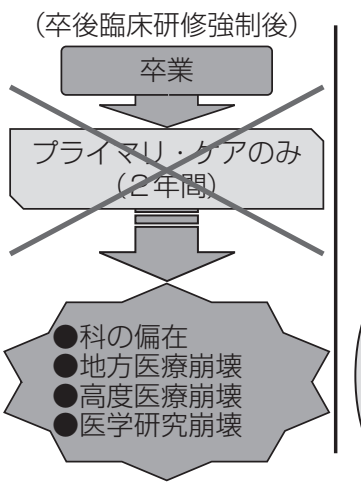

（今後，目指すべき制度）

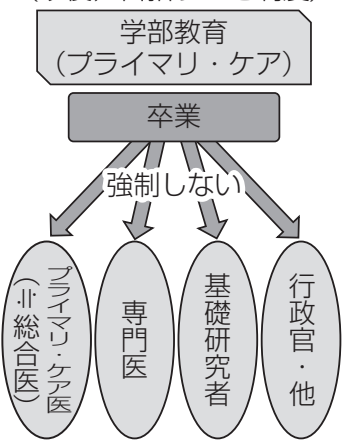

図 10. 医学部卒業生のキャリアパス

は各卒業生にキャリアーパスを選択させるよう にすることが良いと考える(図 10)。事実, 山形 大学医学部で, 医行為を学部学生に施行させた ところ, 平成 3 年の文部省, および厚生省から の医学生の医行為許容範囲は殆ど達成できた事 実がある（図 7)。そうでないと, 図 8 の如く日 本の医学医療は悲惨な結果になると考える. 提 案の結論は（図 9,10）に示す. 